\title{
Temporal Variations of Hydrochemical Characteristics and Their Controlling Factors in the Xiying River Basin in the Eastern Qilian Mountains, China
}

\author{
Dongfeng Ma ${ }^{1}$, Junju Zhou ${ }^{1 *}$, Qiaoqiao Li $^{1}$, Jiao Dou ${ }^{1}$, Jumei Huang ${ }^{1}$, \\ Guofeng Zhu ${ }^{1,2}$, Lanying Wang ${ }^{3}$, Ke Hu${ }^{1}$ \\ ${ }^{1}$ College of Geography and Environment Science, Northwest Normal University, Lanzhou 730070, China \\ ${ }^{2}$ State Key Laboratory of Cryosphere Science, Northwest Institute of Eco-Environment and Resources, \\ Chinese Academy of Sciences, Lanzhou 730000, China \\ ${ }^{3}$ The Administrative Center for China's Agenda 21, Beijing 100038, China
}

Received: 2 October 2020

Accepted: 25 December 2020

\begin{abstract}
Developing a scientific understanding of hydrochemical characteristics and their controlling factors is of great significance in protecting the quality of the water environment and maintaining ecological balance. The article presents the water chemical characteristics and their controlling factors in the Xiying River Basin (XRB) during different flood seasons from April to November, 2015. The results are as follows. The river water was found to be slightly alkaline on the whole and the dominant ions were $\mathrm{Ca}^{2+}$ and $\mathrm{HCO}_{3}^{-}$. The hydrochemical type was $\mathrm{Ca}^{2+}-\mathrm{Mg}^{2+}-\mathrm{HCO}_{3}^{-}$. Besides that, the ion concentrations showed great differences in different periods. From the pre-flood period (PreFP) to post-flood period (PoFP), total dissolved solids (TDS), $\mathrm{Ca}^{2+}, \mathrm{Mg}^{2+}, \mathrm{Na}^{+}$and $\mathrm{SO}_{4}^{2-}$ presented a trend of decreasing first and then increasing. TDS reached its maximum in PreFP. $\mathrm{K}^{+}, \mathrm{NO}_{3}^{-}$and $\mathrm{HCO}_{3}^{-}$presented a trend of increasing first and then decreasing, reaching a maximum in SuFP. Rock weathering is the major controlling mechanism of river hydrochemistry, of which carbonate weathering is the main source of ions, followed by silicate weathering. At the same time, factors such as precipitation, river supply sources, human activities and vegetation cover in different times all have significant influences on river hydrochemistry. The findings in this paper show that we need to adjust cultivated land areas and their space distribution scientifically, strengthen the construction of riverbank forest belts, and make full use of the effects of forest land and grassland. These measures could improve water quality effectively and guarantee water security in middle and lower reaches.
\end{abstract}

Keywords: hydrochemistry, temporal variations, rock weathering, Xiying River Basin

*e-mail: yzh_su@163.com 


\section{Introduction}

The hydrochemical elements of the main ions in the water body can reveal the water rock interaction and the characteristics of various natural (evaporation, precipitation, etc.) and human activities in the watershed, which is of great significance for studying the rock weathering process and the carbon sink effects in the watershed $[1,2]$. On the one hand, hydrochemistry can reflect the complex process of the geological environment and the human activities affecting the water environment [3]. On the other hand, thorough knowledge regarding the hydrochemical characteristics of surface water plays a vital role in assessing water quality, allowing us to understand its suitability for various purposes [4].

River hydrochemistry is predominantly controlled by natural factors such as evaporation crystallization, rock weathering, and atmospheric precipitation [5, 6]. However, water chemistry is also modified by anthropogenic interferences such as forest clearing, agriculture, urbanization, industrial waste, and damming [2]. The properties of the underlying surface in the catchment area, such as climate, geology, vegetation cover etc., have profound effects on hydrochemistry and water resource utilization [7, 8]. For instance, the major sources of $\mathrm{Ca}^{2+}, \mathrm{Mg}^{2+}$, and $\mathrm{HCO}_{3}{ }^{-}$in the hydrosphere come from the interactions between geospheric minerals and atmospheric $\mathrm{CO}_{2}$, whereas $\mathrm{Na}^{+}, \mathrm{Cl}^{-}, \mathrm{NO}_{3}^{-}$and $\mathrm{SO}_{4}{ }^{2-}$ have various sources including the geosphere, atmosphere, biosphere and anthroposphere $[9,10]$. In addition to the discussion of hydrochemical controlling factors, the current research is also based on time scale analysis. With the change of time scale, river hydrochemistry shows different characteristics. These temporal variations mainly include periods before and after the monsoon [7, 11], drought and rainy seasons [12] and seasonal variation [13]. The physical and chemical properties of water bodies, including temperature, $\mathrm{pH}$, electrical conductivity (EC), salinity, total dissolved solids (TDS) and main ions $\left(\mathrm{Ca}^{2+}, \mathrm{Mg}^{2+}, \mathrm{Na}^{+}, \mathrm{K}^{+}, \mathrm{HCO}_{3}^{-}, \mathrm{Cl}^{-}, \mathrm{SO}_{4}^{2-}\right.$, etc.) change greatly $[14,15]$. Generally speaking, due to the dilution effect of precipitation supplement and the change of evaporative concentration, the concentration of major ions in the post-monsoon period is generally lower than pre-monsoon [16]. However, ion concentrations such as $\mathrm{NO}_{3}^{-}$and $\mathrm{HCO}_{3}^{-}$increase in varying degrees in the post-monsoon period. These aforementioned studies have not only clarified the various sources and controlling mechanisms of the hydrogeochemistry in different river basins but also provide important information for understanding the process of material circulation.

The Xiying River, as the largest of the eight tributaries in the upper Shiyang River, has a unique geographical location. It is located in the transition zone of the northwest arid region, east monsoon region and Tibet Plateau high-cold area. The Xiying River Basin
(XRB), which has developed in the Qilian Mountains, is not only a significant water conservation/storage area, but also the main source of the eastern Hexi Corridor's domestic water and agricultural irrigation. It forms an important freshwater resource in the arid and semi-arid areas of northwest China. However, with the increase of human activities since the start of the $21^{\text {st }}$ century, the XRB has become an important but ecologically fragile area. It is facing a situation in which water use contradictions have gradually become prominent and water quality has deteriorated. Against this background, the dynamic change of the water quantity and quality in the XRB is an issue that is worthy of attention. Understanding the hydrochemistry and main weathering processes of the basin is of great significance for protecting and improving the ecological environment of the Qilian Mountains.

In this study, we analyze the main element composition of the XRB using water chemical data from April to November 2015. The aims of this study are as follows: (1) to analyze the hydrochemical characteristics of the XRB and reveal the law of hydrochemical change in different periods; (2) to explore the influence mechanisms of river hydrochemistry and further improve the theories related to hydrochemistry research in mountainous rivers. This study will provide a basis for the scientific utilization and management of water resources in the Qilian Mountains.

\section{Material and Methods}

\section{Study Area}

The XRB $\left(37^{\circ} 28^{\prime}-38^{\circ} 02^{\prime} \mathrm{N}, \quad 101^{\circ} 40^{\prime}-102^{\circ} 23^{\prime} \mathrm{E}\right)$, originating from Lenglongling in the northern slope of the eastern Qilian Mountains, is the largest mountain tributary of the Shiyang River's upstream. It is formed by the confluence of two tributaries of the Ningchan River and Shuiguan River. The Ningchan River is the positive source and the Xiying River flows into the Xiying reservoir after leaving the mountain, with an altitude of $1873-4911 \mathrm{~m}$ and a total basin area of $1727.5 \mathrm{~km}^{2}$. The XRB is located in the transition zone of the eastern monsoon, the arid region of northwest China and the high-cold region of the Qinghai-Tibet Plateau. Its annual precipitation is $400-600 \mathrm{~mm}$. The seasonal distribution is uneven, and the summer precipitation is relatively large. The annual average temperature is below $6^{\circ} \mathrm{C}$, and the temperature difference between day and night is large. The potential evaporation capacity is $705 \mathrm{~mm}$. The main recharge water source of the XRB is the mountain precipitation in summer and autumn, and the average annual runoff is about $3.184 \times 10^{8} \mathrm{~m}^{3}$. The precipitation supply accounts for $60 \%-70 \%$ of the total supply. The proportion of glacial meltwater supply in different periods is also different, accounting for 5\% of the total water in normal water years. Only 3\% are wet years and 7\% are dry years [17]. The Xiying River has two main flood periods, of which June to September 
is the main flood season, and the main supplementary water is atmospheric precipitation. The temperature rises in spring, and the meltwater from glacier and snow from the Lenglongling glacier supplies the runoff and forms the spring flood in May. The eastern Qilian Mountains mainly have Cambrian carbonate rocks, volcanic rocks, Ordovician hydrochloride salt rocks and Archean magmatic rock strata, and most areas correspond to quaternary loess and loose debris. The current geomorphic landscape has been formed under many strong tectonic movements and internal forces (the uplift of the Qinghai-Tibet Plateau, etc.) and external forces (wind and flowing water, etc.) during the geological history period [18]. Mountain hydrothermal conditions have obvious vertical differences, meaning that the increases of vegetation and soil with altitude have obvious vertical differentiation characteristics. There are five band spectra that are roughly divided from low to high altitudes: mountain wilderness steppe-calcareous soil belt $(1700-2300 \mathrm{~m})$, mountain steppe-chestnut soil belt (2300-2500 m), mountain forest steppe-grey brown soil belt $(2500-3300 \mathrm{~m})$, alpine subalpine meadow vegetation-meadow soil zone $(3300-3800 \mathrm{~m})$, and alpine wilderness meadow vegetation-meadow soil ( $\geq 3800 \mathrm{~m})$ [19].

\section{Sample Collection and Analysis}

Different kinds of land use/cover types have obvious effects on a river's hydrochemical characteristics [20]. According to the distribution of land use/cover types and water system characteristics, four sampling points were set up from the upstream to the downstream along the main stream of the Xiying River. These four sampling points were in the typical forest region, the interlaced area of forest and grass, the confluence of typical grassland and the inlet of a reservoir (Fig. 1). Samples were collected monthly from April to November 2015. With two bottles of water samples for each group, a total of 256 available samples were collected. The pre-cleaned $120 \mathrm{ml}$ polyethylene bottles were used to collect samples below $10 \mathrm{~cm}$ of the water surface. The mouth of the bottle was sealed with beeswax, and the sampling points information were labeled. At the same time, GPS was used to mark the coordinates of sampling sites and the geographical environment nearby (Table 1). After the sampling, all samples were frozen and transported to the State Key Laboratory of Cryospheric Science, Northwest Institute of EcoEnvironment and Resources, Chinese Academy of Sciences for testing and analysis.

Before the experiment, the frozen samples were placed in a $23^{\circ} \mathrm{C}$ room to melt naturally. $\mathrm{PH}$ and TDS values were measured using a PHS-SD $\mathrm{pH}$ meter and HI3512 HANNA tester. The instrument was calibrated, then cleaned with distilled water before testing, and filter paper was used to dry the moisture on the surface. The PHS-SD measuring range was 0.00-14.00 pH, and the accuracy was $\pm 0.05 \%$; the measuring range of the HI3512 was $0.00-999.90 \mathrm{mg} \cdot \mathrm{L}^{-1}$, and the accuracy was $\pm 1 \%$. The samples were filtered with $0.45 \mu \mathrm{m}$ JINTENG ${ }^{\circledR}$ nylon filters before the ion concentration was measured. The concentration of the main cations, such as $\mathrm{Ca}^{2+}, \mathrm{Mg}^{2+}, \mathrm{Na}^{+}$and $\mathrm{K}^{+}$, were measured by the Dionex-600 ion chromatograph, and the concentration of the main anions, such as $\mathrm{Cl}^{-}, \mathrm{SO}_{4}^{2-}$

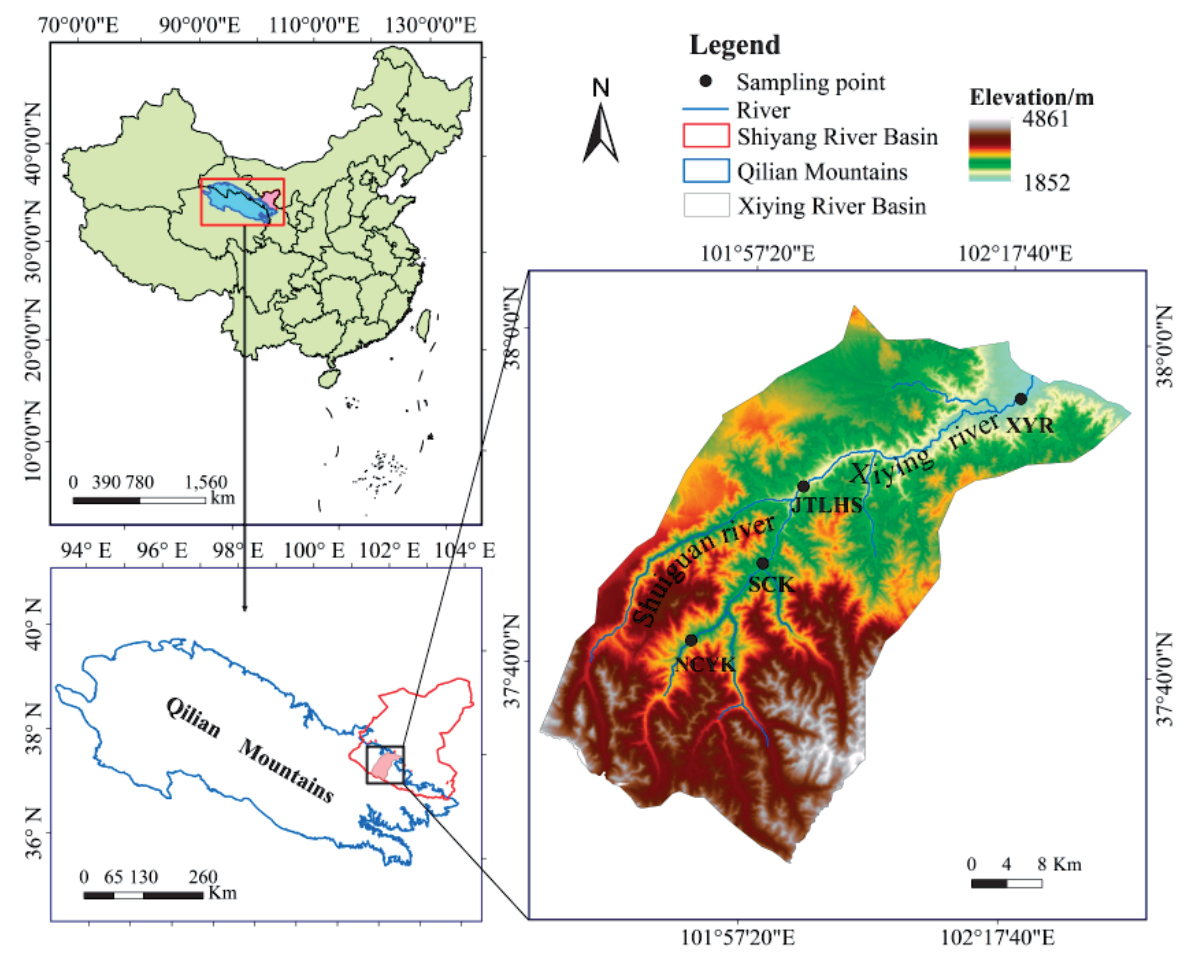

Fig. 1. Study area and sampling points. 
Table 1. Sampling points information.

\begin{tabular}{|c|c|c|c|}
\hline Sampling point & Latitude & Longitude & Elevation (m) \\
\hline NCYK & $37.64^{\circ}$ & $101.52^{\circ}$ & 2741 \\
\hline SCK & $37.72^{\circ}$ & $101.93^{\circ}$ & 2590 \\
\hline JTLHS & $37.86^{\circ}$ & $102.04^{\circ}$ & 2267 \\
\hline XYR & $37.92^{\circ}$ & $102.22^{\circ}$ & 1970 \\
\hline
\end{tabular}

and $\mathrm{NO}_{3}^{-}$, were measured by the Dionex-3000 ion chromatograph. The ion chromatograph precision reached $n \mathrm{~g}^{-1}$, and the measurement error was $<5 \%$. The ion concentrations of $\mathrm{HCO}_{3}^{-}$and $\mathrm{CO}_{3}^{-}$were calculated by two indicators of titration, and the accuracy was $\pm 2 \%$.

\section{Ionic Balance}

In general, the total charge of soluble ions in water is balanced. The accuracy of the measured data was verified by the charge balance method [21, 22]. Through the total positive charge of the water $\left(\mathrm{TZ}^{+}=2 \mathrm{Ca}^{2+}+2 \mathrm{Mg}^{2+}+\mathrm{Na}^{+}+\mathrm{K}^{+}\right)$and the total negative charge of the water $\left(\mathrm{TZ}^{-}=\mathrm{HCO}_{3}^{-}+\mathrm{Cl}^{-}+\mathrm{NO}_{3}^{-}\right.$ $\left.+2 \mathrm{SO}_{4}^{2-}\right)$, the normalized inorganic charge balance (NICB) was calculated in the XRB (Formula (1)). When $-5 \%<\mathrm{NICB}<5 \%$, the soluble ions in the water tended to balance, and the measured data were basically found to be accurate.

$$
\mathrm{NICB}=\left(\mathrm{TZ}^{+}-\mathrm{TZ}\right) /\left(\mathrm{TZ}^{+}\right)^{*} 100 \%
$$

After calculation, the change range of NICB in the XRB was $-4.20 \% \sim 8.94 \%$, among which the NICB value of $93.75 \%$ of samples was less than $5 \%$; thus, the data quality was reliable.

\section{The Determination of Flood Periods}

The precipitation and river discharge in the XRB from June to September are relatively large (Fig. 2), which is the summer flood period (SuFP). The precipitation is small and the flow is large in May, which is the typical spring flood period (SpFP). April's precipitation and flow are both small, which is the pre-flood period (PreFP); from October to November, precipitation and flow significantly decreased, thus corresponding to the post-flood period (PoFP).

\section{Results}

\section{General Characteristics of Hydrochemistry}

The concentration changes of $\mathrm{Ca}^{2+}, \mathrm{HCO}_{3}^{-}$and $\mathrm{Cl}^{-}$in the river are most obvious in Table 2 . The concentration of $\mathrm{Ca}^{2+}$ was the highest among cations and the concentration of $\mathrm{HCO}_{3}^{-}$was the highest among anions, while the $\mathrm{Cl}^{-}$concentration was the lowest. The average concentration of cations and anions in the four periods showed consistency in the order $\mathrm{Ca}^{2+}>\mathrm{Mg}^{2+}>\mathrm{Na}^{+}>\mathrm{K}^{+}$, and the dominant cation was $\mathrm{Ca}^{2+}$; and in the order $\mathrm{HCO}_{3}>\mathrm{SO}_{4}{ }^{2-}>\mathrm{NO}_{3}>\mathrm{Cl}^{-}$, and the dominant anion was $\mathrm{HCO}_{3}$ - The changes of ion concentrations in different periods were different (Fig. 3). The concentration of $\mathrm{Ca}^{+}, \mathrm{Mg}^{2+}$ and $\mathrm{SO}_{3}{ }^{2+}$ was higher in the PreFP, decreased after entering the flood period, and gradually rose in the PoFP. The concentration of $\mathrm{NO}_{3}^{-}, \mathrm{K}^{+}$and $\mathrm{HCO}_{3}^{-}$increased after entering the flood season, then reached the maximum in the SuFP and decreased in the PoFP.

The $\mathrm{pH}$ (hydrogen ion concentration index) of the river water in the four periods was weakly alkaline. Of these periods, the $\mathrm{pH}$ in SuFP was the lowest, with an average value of 7.90, and the maximum value was 8.21 in SpFP. According to the guidelines for drinking water quality published by the World Health Organization and the Chinese National Drinking Water Standard $(6.5<\mathrm{pH}<8.5)[23,24]$, the river water of the XRB was suitable for drinking and living production.

TDS represents the total amount of solid matter dissolved in water. The river's TDS generally decreased first and then increased from PreFP to PoFP, and the minimum value appeared in $\operatorname{SuFP}\left(272 \mathrm{mg} \cdot \mathrm{L}^{-1}\right)$ while the maximum value appeared in PreFP (Fig. 3c). The TDS average value was $330.47 \mathrm{mg} \cdot \mathrm{L}^{-1}$, which was higher than the average of rivers around the world $\left(115 \mathrm{mg} \cdot \mathrm{L}^{-1}\right)$; meanwhile, it was also higher than the upstream of Heihe River in the northwest arid region $\left(\mathrm{TDS}=303.4 \mathrm{mg} \cdot \mathrm{L}^{-1}\right)$ [25] and the upper Shule River $\left(\mathrm{TDS}=177.68 \mathrm{mg} \cdot \mathrm{L}^{-1}\right)$ [26], while it was lower than the Tarim River $\left(\mathrm{TDS}=656 \mathrm{mg} \cdot \mathrm{L}^{-1}\right)$ [27] and the Yellow River $\left(\mathrm{TDS}=453 \mathrm{mg} \cdot \mathrm{L}^{-1}\right)[28]$.

\section{Hydrochemical Types}

A Piper diagram can directly reveal the composition of ions in a water body, and simply classify the hydrochemical types of the studied water body.

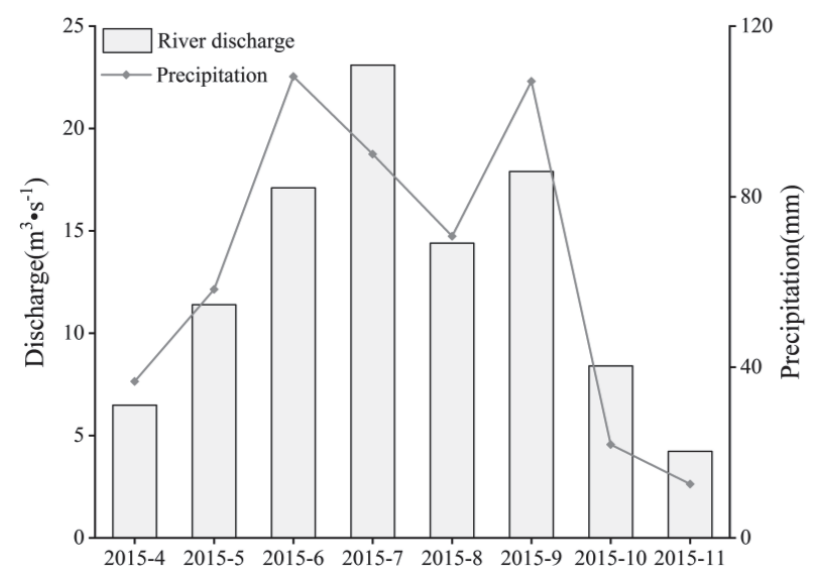

Fig. 2. River discharge and precipitation in the XRB. 
Table 2. Chemical analysis and statistics of river samples in different seasons.

\begin{tabular}{|c|c|c|c|c|c|c|c|c|c|c|c|c|c|}
\hline \multicolumn{2}{|c|}{ Parameters } & $\mathrm{Ca}^{2+}$ & $\mathrm{Mg}^{2+}$ & $\mathrm{Na}^{+}$ & $\mathrm{K}^{+}$ & $\mathrm{HCO}_{3}^{-}$ & $\mathrm{Cl}^{-}$ & $\mathrm{SO}_{4}^{2-}$ & $\mathrm{NO}_{3}^{-}$ & TDS & $\mathrm{pH}$ & NICB (\%) & Rainfall (mm) \\
\hline \multirow{3}{*}{$\begin{array}{l}\text { PreFP } \\
(4)\end{array}$} & Min & 34.26 & 15.12 & 7.32 & 0.80 & 219.87 & 1.82 & 35.35 & 2.23 & 312 & 7.91 & 0.75 & \multirow{3}{*}{34.75} \\
\hline & Max & 42.33 & 29.41 & 10.07 & 1.10 & 255.89 & 3.16 & 78.03 & 3.63 & 461 & 8.30 & 4.47 & \\
\hline & Avg & 37.56 & 20.24 & 8.73 & 0.89 & 241.88 & 2.39 & 58.24 & 2.92 & 370.5 & 8.10 & 3.40 & \\
\hline \multirow{3}{*}{$\begin{array}{l}\text { SpFP } \\
\text { (5) }\end{array}$} & Min & 31.01 & 7.96 & 3.96 & 0.73 & 214.87 & 0.98 & 14.25 & 2.13 & 203 & 8.12 & -0.15 & \multirow{3}{*}{43.22} \\
\hline & Max & 35.73 & 17.22 & 11.07 & 1.39 & 258.35 & 3.68 & 52.27 & 3.87 & 378 & 8.26 & 3.22 & \\
\hline & Avg & 33.23 & 13.43 & 6.76 & 1.00 & 245.93 & 1.78 & 40.59 & 2.79 & 281.3 & 8.21 & 0.99 & \\
\hline \multirow{3}{*}{$\begin{array}{l}\text { SuFP } \\
(6-9)\end{array}$} & Min & 22.53 & 8.31 & 3.20 & 0.39 & 186.65 & 0.17 & 20.01 & 2.26 & 114 & 7.60 & -4.20 & 70.76 \\
\hline & Max & 40.45 & 21.65 & 8.43 & 1.03 & 339.87 & 3.27 & 69.11 & 4.42 & 376 & 8.13 & 4.29 & 108.18 \\
\hline & Avg & 32.77 & 15.71 & 6.01 & 1.18 & 279.15 & 1.74 & 36.63 & 3.46 & 272 & 7.90 & -0.46 & 93.99 \\
\hline \multirow{3}{*}{$\begin{array}{c}\text { PoFP } \\
(10-11)\end{array}$} & Min & 34.64 & 11.81 & 3.87 & 0.78 & 236.23 & 0.40 & 38.79 & 1.79 & 269 & 7.80 & 1.71 & 12.64 \\
\hline & Max & 44.18 & 26.26 & 10.01 & 1.83 & 276.96 & 4.48 & 79.99 & 3.84 & 382 & 8.33 & 8.94 & 21.89 \\
\hline & Avg & 37.47 & 19.15 & 7.45 & 0.87 & 253.97 & 1.69 & 58.00 & 2.99 & 340.9 & 8.03 & 3.75 & 17.27 \\
\hline
\end{tabular}

All values are in $\mathrm{mg} \cdot \mathrm{L}^{-1}$ except $\mathrm{pH}$ and rainfall $(\mathrm{mm})$.

There are four kinds of hydrochemistry according to the different ion concentrations: $\mathrm{Ca}^{2+}-\mathrm{Mg}^{2+}-\mathrm{SO}_{4}{ }^{2-}-\mathrm{Cl}$; $\mathrm{Ca}^{2+}-\mathrm{Mg}^{2+}-\mathrm{HCO}_{3}^{-} ; \mathrm{Na}^{+}-\mathrm{HCO}_{3}^{-} ; \mathrm{Na}^{+}-\mathrm{SO}_{4}{ }^{2-}-\mathrm{Cl}^{-}$[11]. The Piper diagram (Fig. 4) in this work shows that more than $93 \%$ of river water samples are located in the $\mathrm{Ca}^{2+}$ region in the cation triangle; all samples are located in the $\mathrm{HCO}_{3}^{-}$region in the anion triangle, indicating that the dominant cations and anions in the water are $\mathrm{Ca}^{2+}$ and $\mathrm{HCO}_{3}^{-}$, respectively. In terms of time, the hydrochemical types do not change with the change of flood season. All samples in the four periods are located in the area of the second type of water, accounting for $100 \%$. Therefore, the hydrochemical type of XRB is $\mathrm{Ca}^{2+}-\mathrm{Mg}^{2+}-\mathrm{HCO}_{3}{ }^{-}$.
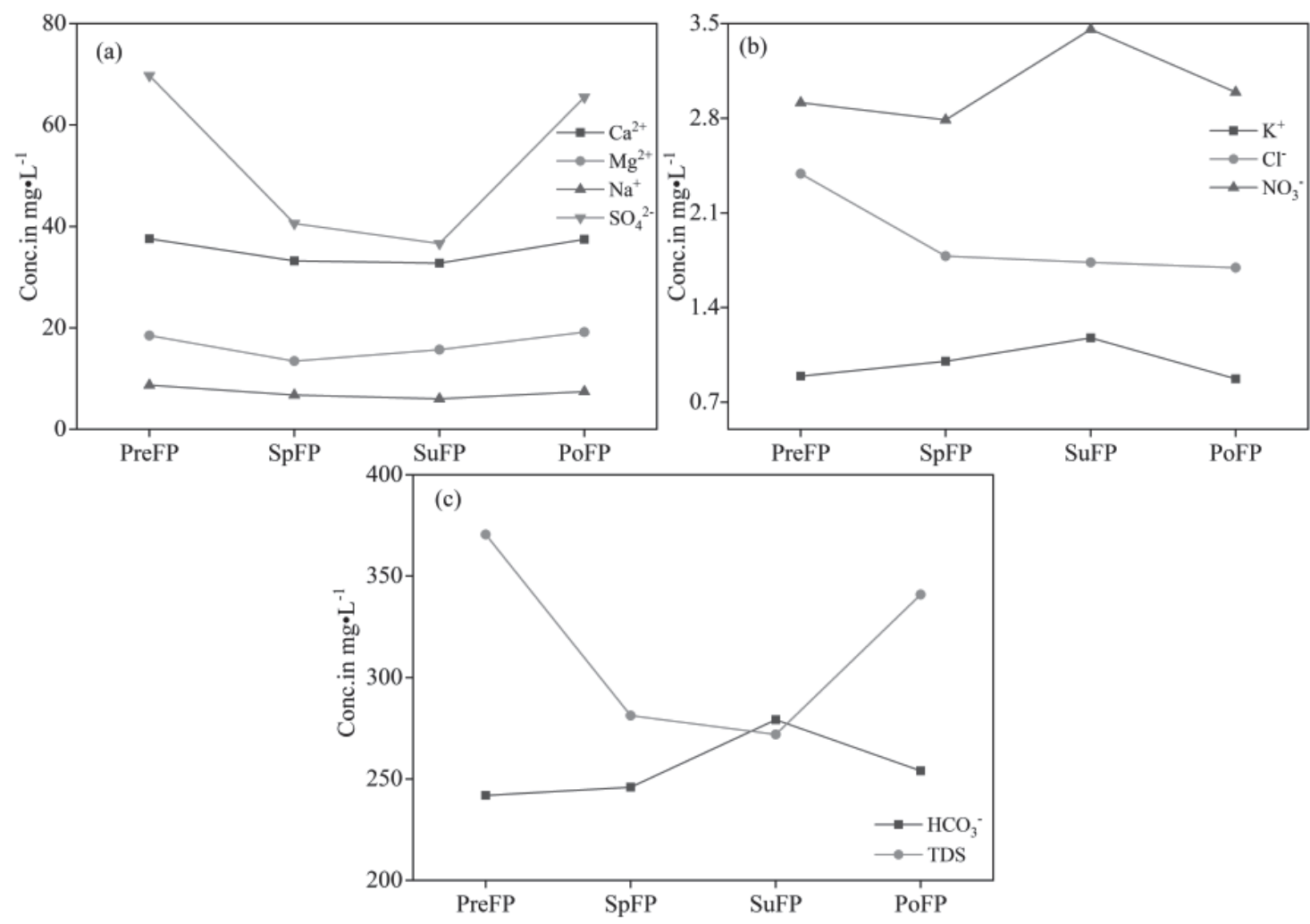

Fig. 3. Temporal variation characteristics of hydrochemistry. 


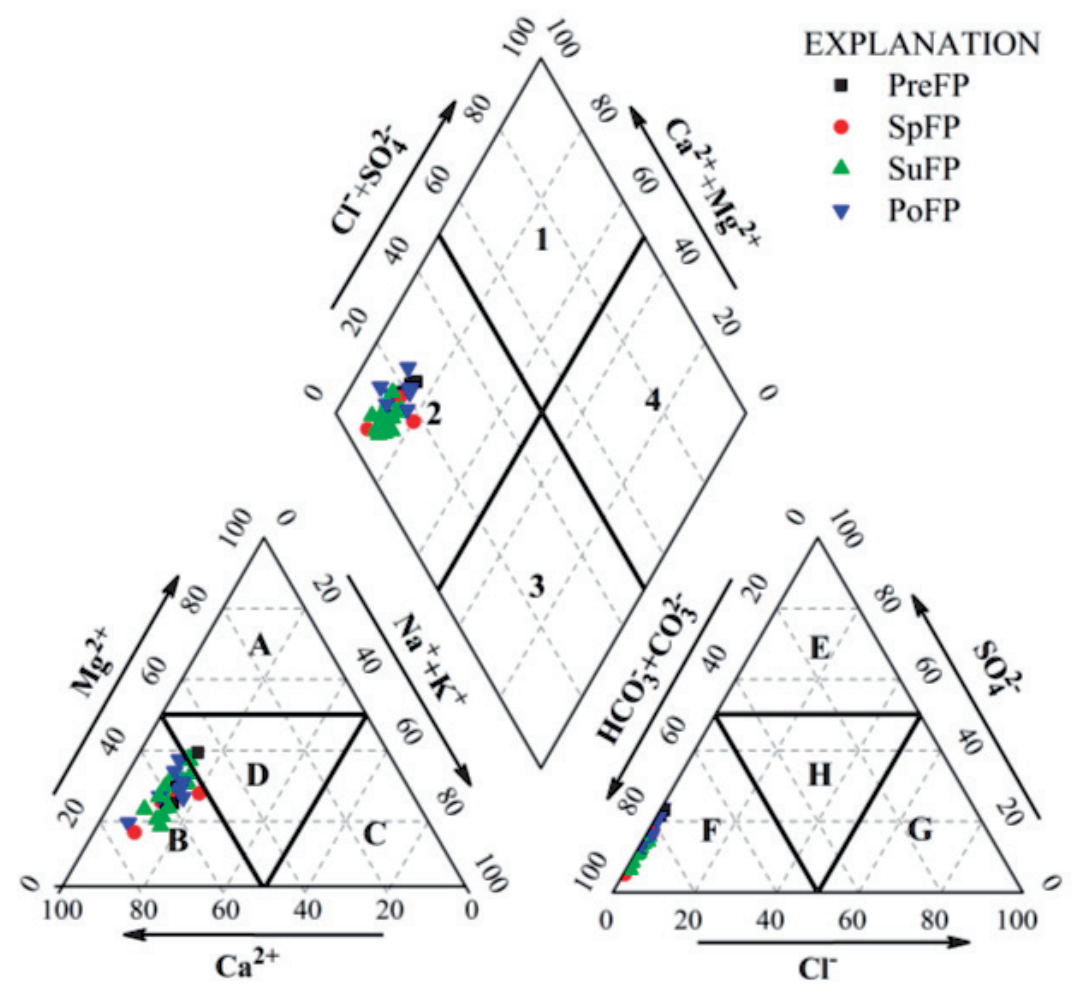

Fig. 4. The Piper diagram of the major ions in different seasons.

(1: $\mathrm{Ca}^{2+}-\mathrm{Mg}^{2+}-\mathrm{SO}_{4}^{2-}-\mathrm{Cl}^{-} ; 2: \mathrm{Ca}^{2+}-\mathrm{Mg}^{2+}-\mathrm{HCO}_{3}^{-} ; 3: \mathrm{Na}^{+}-\mathrm{HCO}_{3}^{-} ; 4: \mathrm{Na}^{+}-\mathrm{SO}_{4}^{2-}-\mathrm{Cl} ; \mathrm{A}: \mathrm{Mg}^{2+} ; \mathrm{B}: \mathrm{Ca}^{2+} ; \mathrm{C}: \mathrm{Na}^{+}-\mathrm{K}^{+} ; \mathrm{D}: \mathrm{Mixed} \mathrm{Zone} ; \mathrm{E}: \mathrm{SO}_{4}^{2-}$; F: $\mathrm{HCO}_{3}^{-} ; \mathrm{G}: \mathrm{Cl}^{-} ; \mathrm{H}$ : Mixed Zone)

\section{Discussion}

\section{Controlling Factors of River Hydrochemistry}

\section{Rock Weathering}

A Gibbs plot can qualitatively determine the influence of regional evaporite dissolution, atmospheric precipitation and rock weathering on river hydrochemistry, and then determine the process of controlling the solute dissolution [29]. In the Gibbs plot of XRB (Fig. 5(a, b)), the water samples' $\mathrm{Na}^{+} /\left(\mathrm{Na}^{+}+\mathrm{Ca}^{2+}\right)$ levels in the four periods were less than 0.4 and $\mathrm{Cl}^{-} /\left(\mathrm{Cl}^{-}+\mathrm{HCO}_{3}^{-}\right)$levels were less than 0.1. The ratio of anions and cations was low, but the TDS was at a medium level. The sampling points were located in the rock weathering area, indicating that the water chemistry of the XRB was mainly controlled by rock weathering, which was the main factor affecting the water chemistry in this area.

In order to further clarify the rock weathering type, this study used the $\mathrm{Na}^{+}$standardized molar ratio. Through the ratio of molar concentration of $\mathrm{Ca}^{2+}, \mathrm{Mg}^{2+}$, $\mathrm{HCO}_{3}^{-}$and $\mathrm{Na}^{+}$, the ratio can distinguish the influence of different rock and mineral weathering events on river solute [30]. The effects of the different lithologies on the solutes in the XRB are shown in Fig. 5c) and 5d). In the three periods (PreFP, SpFP and SuFP), the river samples fall in the controlled area of carbonate rock and silicate rock, which was in contrast to the evaporative dissolution control. They were closer to the control of carbonate rock in PoFP. The above results show that the hydrochemistry of XRB was influenced by the same lithology in the four periods. Combined with the geological conditions in the southern Qilian Mountains, metamorphic sandstone, clastic rock, carbonate rock, medium-basic-medium-acid volcanic rock and magmatic rock from the Cambrian, Ordovician and Silurian were distributed in the basin [31], and it can be stated that the river water chemistry of the XRB in the four periods was mainly controlled by carbonate weathering and then silicate weathering secondly; furthermore, the influence of the evaporation was very small and could be ignored.

\section{The Influence of Lithology}

The equivalent ratio of $\mathrm{Ca}^{2+}$ and $\mathrm{Mg}^{2+}$ (Fig. 6a) can be used to judge their source in water [32]. When $1<\mathrm{Ca}^{2+} / \mathrm{Mg}^{2+}<2$, it means that the dissolution of dolomite in carbonate rocks is the main source of ions. When $\mathrm{Ca}^{2+} / \mathrm{Mg}^{2+}>2$, silicate rocks offer more solute to the river water. As can be seen from Fig. 6a), most samples showed a ratio between 1 and 2, and the ratio of these samples accounted for $75 \%$ in Pre-FP, SpFP and SuFP but PoFP (62.5\%) (Table. 3). This suggested that the dissolution of carbonate rocks was the main source of ions and the weak process of ions exchange 

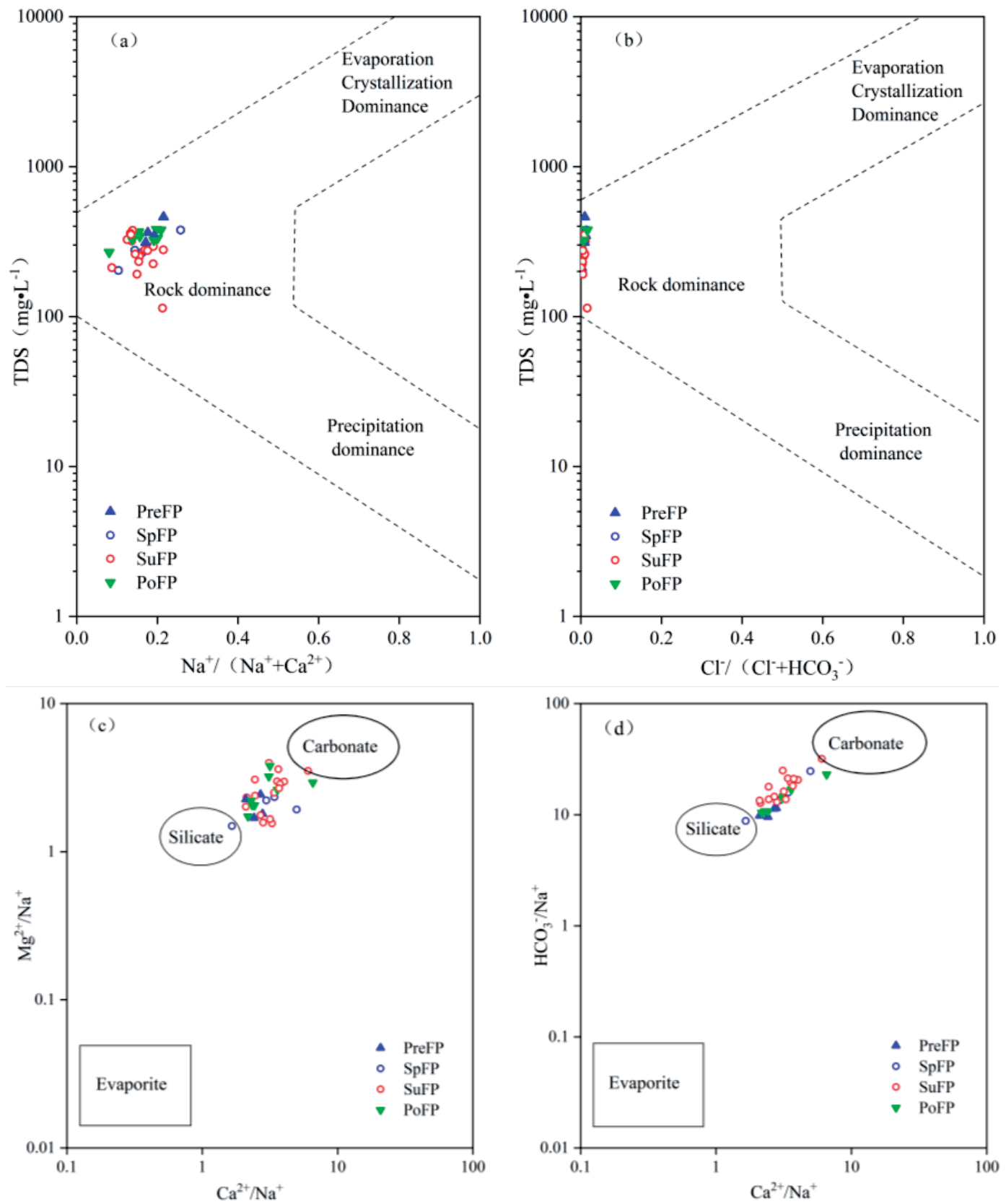

Fig. 5. The Gibbs plot (a and b) and ions ratios (c and d) in different seasons.

in SuFP. In other periods, it had little impact. In order to reveal the process of the dissolution of carbonate rocks further, the experiment compared $\mathrm{Ca}^{2+}+\mathrm{Mg}^{2+}$ and $\mathrm{Na}^{+}+\mathrm{K}^{+}$equivalents. Fig. 6c) suggests that all sample points of $\mathrm{Ca}^{2+}+\mathrm{Mg}^{2+}$ in the four periods was higher than the points of $\mathrm{Na}^{+}+\mathrm{K}^{+}$. All sample points were far from the ratio line, which means that ions such as $\mathrm{Ca}^{2+}$ and $\mathrm{Mg}^{2+}$ in the catchment of the XRB mainly originated from the dissolution of carbonate rocks. The reaction process is as follows (Formulas 2 and 3):

$$
\begin{gathered}
\mathrm{CaMg}\left(\mathrm{CO}_{3}\right)_{2}+2 \mathrm{CO}_{2} \\
+2 \mathrm{H}_{2} \mathrm{O} \rightarrow 4 \mathrm{HCO}_{3}^{-}+\mathrm{Ca}^{2+}+\mathrm{Mg}^{2+} \\
\mathrm{CaCO}_{3}+\mathrm{CO}_{2}+\mathrm{H}_{2} \mathrm{O} \rightarrow \mathrm{Ca}^{2+}+2 \mathrm{HCO}_{3}^{-}
\end{gathered}
$$

The value of $\mathrm{Cl} / \mathrm{Na}^{+}$was used to determine the source of salt in water [33]. When $\mathrm{Cl}^{-} / \mathrm{Na}^{+}<1$, silicate was corroded, and $\mathrm{CO}_{2}$ brought by river water and precipitation contributed to the dissolution of feldspathoid and released $\mathrm{Na}^{+}, \mathrm{K}^{+}$and $\mathrm{HCO}_{3}^{-}$(Formulas 4-7). All samples in the four periods lay under the ratio line of 1 (Fig. 6b), which meant that the weathering and corrosion of silicate was very severe in the catchment of the XRB, and the weathering of silicate was one of the main sources of ions.

$$
\begin{gathered}
2 \mathrm{NaAlSi}_{3} \mathrm{O}_{8}+2 \mathrm{CO}_{2}+11 \mathrm{H}_{2} \mathrm{O} \rightarrow \mathrm{Al}_{2} \mathrm{Si}_{2} \mathrm{O}_{5}(\mathrm{OH})_{4} \\
+2 \mathrm{Na}^{+}+2 \mathrm{HCO}_{3}^{-}+4 \mathrm{H}_{4} \mathrm{SiO}_{4}
\end{gathered}
$$




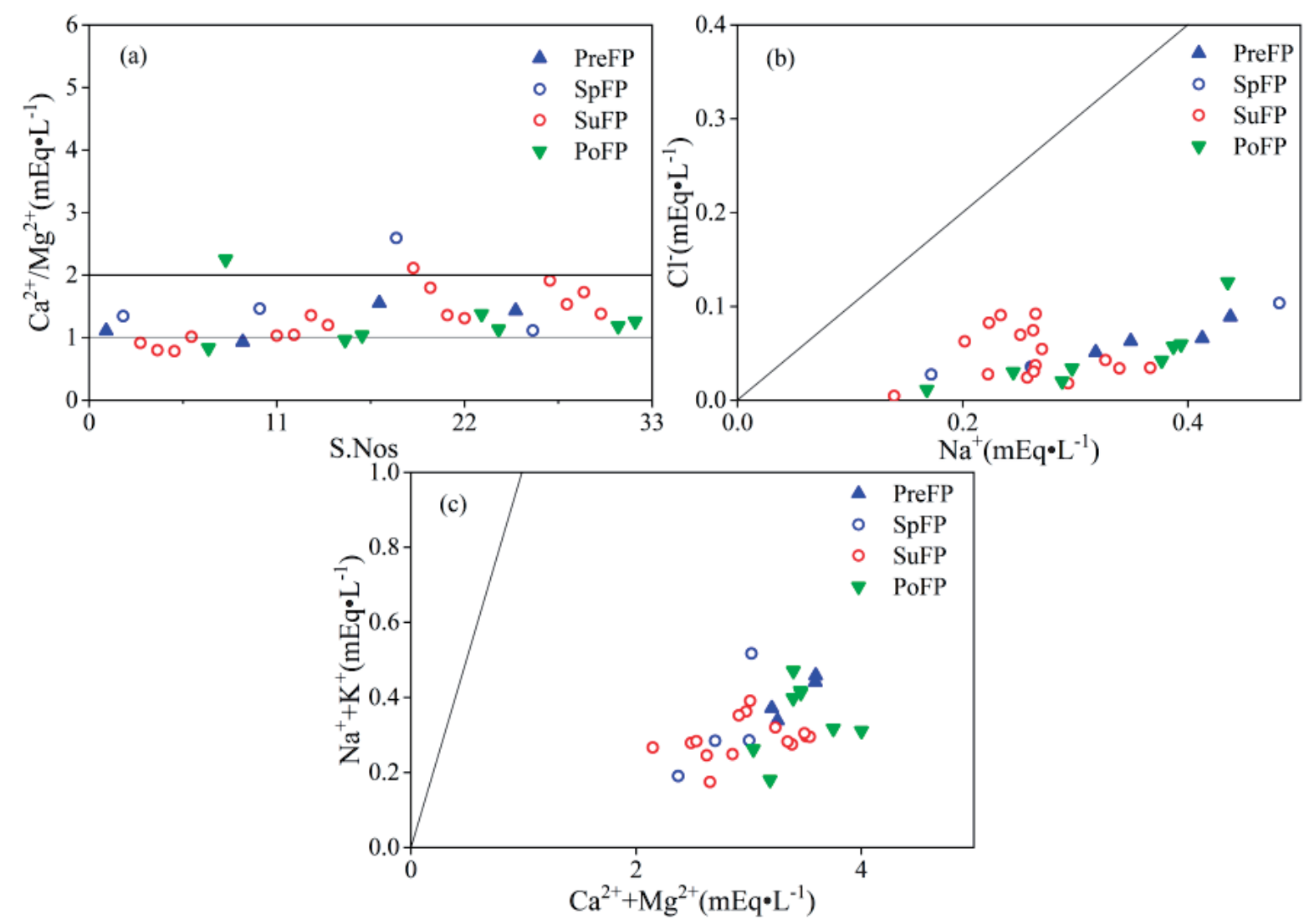

Fig. 6. Different ions equivalent ratios: a) $\mathrm{Ca}^{2+} / \mathrm{Mg}^{2+}$, b) $\mathrm{Na}^{+}$versus $\mathrm{Cl}^{-}$, c) $\mathrm{Ca}^{2+}+\mathrm{Mg}^{2+}$ versus $\mathrm{Na}^{+}+\mathrm{K}^{+}$.

$$
\begin{aligned}
2 \mathrm{KAlSi}_{3} \mathrm{O}_{8}+ & 2 \mathrm{CO}_{2}+6 \mathrm{H}_{2} \mathrm{O} \rightarrow \mathrm{Al}_{2} \mathrm{Si}_{2} \mathrm{O}_{10}(\mathrm{OH})_{4} \\
+ & 2 \mathrm{~K}^{+}+2 \mathrm{HCO}_{3}^{-}+4 \mathrm{H}_{4} \mathrm{SiO}_{4} \\
\mathrm{CaAl}_{2} \mathrm{Si}_{2} \mathrm{O}_{8}+ & 2 \mathrm{CO}_{2}+3 \mathrm{H}_{2} \mathrm{O} \rightarrow \mathrm{Al}_{2} \mathrm{Si}_{2} \mathrm{O}_{5}(\mathrm{OH})_{4} \\
+ & 2 \mathrm{Ca}^{2+}+2 \mathrm{HCO}_{3}^{-} \\
\mathrm{MgSiO}_{4} & +4 \mathrm{CO}_{2}+4 \mathrm{H}_{2} \mathrm{O} \rightarrow 2 \mathrm{Mg}^{2+} \\
+ & 4 \mathrm{HCO}_{3}^{-}+\mathrm{H}_{4} \mathrm{SiO}_{4}
\end{aligned}
$$

Generally speaking, in the area controlling by carbonate rocks and silicate rocks, $\mathrm{HCO}_{3}^{-}$mainly originates from carbonate dissolution, the atmosphere and $\mathrm{CO}_{2}$ in soil. $\mathrm{HCO}_{3}^{-}$is restricted by the $\mathrm{Ca}^{2+}$ concentration, whose content is low in water with a high $\mathrm{Ca}^{2+}$ concentration. The $\mathrm{HCO}_{3}^{-}$content of the low-salinity water body was higher than that for $\mathrm{SO}_{4}{ }^{2-}$ and $\mathrm{Cl}^{\text {. The }} \mathrm{HCO}_{3}{ }^{-}$concentration of the XRB in flood season was higher than other times, and was highest in SuFP and lowest in PreFP. The main reasons for

Table 3. Ions ratio (\%).

\begin{tabular}{|c|c|c|c|c|}
\hline $\mathrm{M}\left(\mathrm{Ca}^{2+} / \mathrm{Mg}^{2+}\right)$ & PreFP & SpFP & SuFP & PoFP \\
\hline $\mathrm{M}<1$ & 25 & 0 & 18.75 & 25 \\
\hline $1<\mathrm{M}<2$ & 75 & 75 & 75 & 62.5 \\
\hline $\mathrm{M}>2$ & 0 & 25 & 6.25 & 12.5 \\
\hline
\end{tabular}

this were that during the SuFP, the $\mathrm{pH}$ is low, and the $\mathrm{CO}_{2}$ brought by precipitation promoted the dissolution of carbonate rocks, resulting in an increase in the concentration of $\mathrm{HCO}_{3}^{-}$in the river water (Formulas $4-8)$.

$$
\begin{gathered}
\mathrm{Na}_{0.62} \mathrm{Ca}_{0.38} \mathrm{Al}_{1.38} \mathrm{Si}_{2.62} \mathrm{O}_{8}+1.38 \mathrm{CO}_{2}+4.55 \mathrm{H}_{2} \mathrm{O} \\
\rightarrow 0.69 \mathrm{Al}_{2} \mathrm{Si}_{2} \mathrm{O}_{5}(\mathrm{OH})_{4}+0.62 \mathrm{Na}^{+}+0.38 \mathrm{Ca}^{2+} \\
+1.38 \mathrm{HCO}_{3}^{-}+1.24 \mathrm{H}_{2} \mathrm{SiO}_{4}
\end{gathered}
$$

Other Influencing Factors

In PreFP, there was less precipitation and mainly snowfall. Groundwater supply was the main form of runoff. Because of the interaction between water and rocks - i.e., rock weathering - the concentration of ions and TDS in the underground of the XRB was higher. Many studies have indicated that woodland and grassland can purify water, reduce water chemical pollution and improve river environment quality [20, 34-36]. The plants grew less well, and their purifying effect on the water was weaker, leading to higher concentration of TDS and most ions $\left(\mathrm{Ca}^{2+}, \mathrm{Mg}^{2+}, \mathrm{Na}^{+}\right.$, $\mathrm{SO}_{4}^{2-}$ and $\mathrm{Cl}^{-}$) except $\mathrm{K}^{+}$and $\mathrm{NO}_{3}^{-}$.

In $\mathrm{SpFP}$, the precipitation was reduced, accounting for $11.53 \%$ of the annual total amount. The temperature rose and the amount of glacier and snow meltwater increased in this period; thus the main supply sources 
of runoff were groundwater and glacier and snow meltwater. However, the ion concentration of glacier and snow melt was lower than groundwater [37], and increasing amounts of glacier and snow meltwater flooded into the runoff, consistently reducing the concentration of most ions in water.

In SuFP, precipitation accounted for $74.38 \%$ of the annual total amount. The main supply source of runoff was precipitation. Precipitation could bring soluble materials in water, but the ion concentration and TDS of precipitation was lower than groundwater and glacier. This led to a low concentration because of the dilution effect. Furthermore, in the XRB, vegetation growth was best in SuFP, which caused forest land and grassland to have the strongest purification effect on the water body. For this reason, the ion concentration $\left(\mathrm{Ca}^{2+}, \mathrm{Mg}^{2+}, \mathrm{Na}^{+}\right.$ and $\mathrm{SO}_{4}{ }^{2-}$ ) and TDS were low. At the same time, this was the most active and key period of cultivation and fertilizer use $\left(\mathrm{KNO}_{3}\right.$ and $\left.\mathrm{NH}_{4} \mathrm{NO}_{3}\right)$. The cultivated land area of the XRB was about $10.17 \mathrm{~km}^{2}$ and concentrated on the riverbanks after the JTLHS. Some ions such as $\mathrm{K}^{+}$and $\mathrm{NO}_{3}^{-}$in soil and cultivated land were washed into the river, forming the highest concentration at this time.

Entering October, the main supply sources of runoff became groundwater and glacier meltwater as the precipitation decreased. At the same time, with withered plants and a weaker purifying effect, glacier meltwater and groundwater brought large amounts of soluble rock-weathering materials into the river, contributing to the obvious increase of the TDS and increasing the concentration of many ions concentration $\left(\mathrm{Ca}^{2+}\right.$, $\mathrm{Mg}^{2+}$ and $\mathrm{SO}_{4}^{2-}$ ).The concentration of $\mathrm{K}^{+}$and $\mathrm{NO}_{3}^{-}$ obviously decreased because of the gradual decline in agricultural activities.

\section{Conclusions}

Developing a scientific understanding of river hydrochemistry is of great significance for understanding hydrogeochemical processes and maintaining ecological balance. Based on measured data and qualitative methods (Piper diagram, Gibbs plot and ions ratios), we discussed the hydrochemical characteristics and their controlling mechanisms in the XRB. This study shows that the dominant ions of the XRB in the flood period were both $\mathrm{Ca}^{2+}$ and $\mathrm{HCO}_{3}$. The kind of river hydrochemistry was $\mathrm{Ca}^{2+}-\mathrm{Mg}^{2+}-$ $\mathrm{HCO}_{3}^{-}$, and the water was slightly alkaline on the whole. The ions concentrations showed great differences in the four periods.

Regarding the mechanism of water chemistry control, we found that rock weathering, especially carbonate rock weathering and silicate rock weathering, were the main sources of ions. Atmospheric precipitation, river supply forms, the vegetation status on the surface and human activities could all influence the river hydrochemistry. First of all, precipitation and glacial meltwater with lower ion concentrations and groundwater with higher concentrations cause different levels of replenishment for rivers in different periods, meaning that TDS and most ion concentrations are lowest in spring and summer floods and higher for the rest of the year. Secondly, the surface vegetation changes obviously in different periods, which means that the degree of water purification changes. Especially in the summer flood period, the surface vegetation grows well and has a strong purification effect on the river water, which is also one of the reasons for the low ion concentration in the river water. Finally, the expansion of riparian farmland and the use of chemical fertilizers in agricultural production activities have a great impact on the river ion concentration (especially $\mathrm{K}^{+}, \mathrm{NO}_{3}^{-}$and $\mathrm{HCO}_{3}^{-}$), which is an important reason for the change of ion concentration in SuFP. Based on the above conclusions, we believe that the adjustment of the cultivated land area and its spatial distribution in the basin, strengthening the protection of the riparian forest zone and making full use of the purification effect of forest land and grassland, can effectively improve water quality and guarantee water security in the middle and lower reaches.

\section{Acknowledgements}

This research was financially supported by National Natural Science Foundation of China (NO.41761047, 41661005 and 41661084) and Autonomous project of State Key Laboratory of Cryosphere Sciences (NO.SKLCS-ZZ-2017). We would like to thank our colleagues in the Northwest Normal University for their help in the writing process. We are grateful to anonymous reviewers and editorial staff for their constructive and helpful suggestions.

\section{Conflict of Interest}

The authors declare no conflict of interest.

\section{References}

1. ZAKHAR S., VLADIMIR D., ALINA G., DMITRY D., ALEXANDER C., EVGENY S. The hydrochemistry and recent sediment geochemistry of small lakes of Murmansk, arctic zone of Russia. Water (Switzerland), 12, 1, 2020.

2. LI S.Y., LU X.X., BUSH R.T. Chemical weathering and $\mathrm{CO}_{2}$ consumption in the Lower Mekong River. Science of the Total Environment, 472, 162, 2014.

3. ZHANG Q.H., SUN P.A., HE S.Y., WEN H., LIU M.L., YU S. Fate and Origin of Major Ions in River Water in the Lhasa River Basin, Tibet. Environmental Science, 39, $1065,2018$.

4. WU H.W., WU J.L., LI J., FU C.S. Spatial variations of hydrochemistry and stable isotopes in mountainous river water from the Central Asian headwaters of the Tajikistan Pamirs. Catena, 193, 104639, 2020. 
5. GIBBS R.J. Mechanisms Controlling World Water Chemistry. Science, 170, 1088, 1970.

6. WU W.H. Hydrochemistry of inland rivers in the north Tibetan Plateau: Constraints and weathering rate estimation. Science of the Total Environment, 541, 468, 2016.

7. PANT R.R., ZHANG F., REHMAN F.U., WANG G.X., YE M., ZENG C., TANG H.D. Spatiotemporal variations of hydrogeochemistry and its controlling factors in the Gandaki River Basin, Central Himalaya Nepal. Science of the Total Environment, 622-623, 770, 2018.

8. SEEYAN S. Hydrochemical assessment and groundwater quality of Koysinjaq area in Kurdistan Region-Iraq. Arabian Journal of Geosciences, 13, 12, 2020.

9. HAIDARY A., AMIRI B.J., ADAMOWSKI J., FOHRER N., NAKANE K. Assessing the Impacts of Four Land Use Types on the Water Quality of Wetlands in Japan. Water Resources Management, 27, 2217, 2013.

10. HUANG X., SILlANPAA M., GJESSING E.T., VOGT R.D. Water quality in the Tibetan Plateau: Major ions and trace elements in the headwaters of four major Asian rivers. Science of the Total Environment, 407, 6242, 2009.

11. SRINIVASAMOORTHY K., GOPINATH M., CHIDAMBARAM S., VASANTHAVIGAR M., SARMA V.S. Hydrochemical characterization and quality appraisal of groundwater from Pungar sub basin, Tamilnadu, India. Journal of King Saud University - Science, 26, 37, 2014.

12. LI Z., XIAO J., EVARISTO J., LI Z. Spatiotemporal variations in the hydrochemical characteristics and controlling factors of streamflow and groundwater in the Wei River of China. Environmental Pollution, 254, 113006. 2019.

13. ZHOU J.J., XIANG J., ZHU G.F., LEI L., CAO J.J., SHI W., WEI W., HUANG M.H., FENG W. Spatiotemporal hydrochemical variations in river water in the Qilian Mountains and their sources: a case study of the Binggou River Basin. Journal of Water, Sanitation and Hygiene for Development, 9, 731, 2019.

14. SREEDEVI P.D., AHMED S. Using Ion-Selective Electrode for Estimation of Fluoride Contaminated Seasons for Groundwater. Advanced Electrochemistry, 1, 75, 2013

15. YARLAGADDA S., GUDE V.G., CAMACHO L.M., PINAPPU S., DENG S.G. Potable water recovery from As, $\mathrm{U}$, and $\mathrm{F}$ contaminated ground waters by direct contact membrane distillation process. Journal of Hazardous Materials, 192, 1388, 2011.

16. SUBBA RAO N. Seasonal variation of groundwater quality in a part of Guntur District, Andhra Pradesh, India. Environmental Geology, 49, 413, 2006.

17. HU Z.Y. Evolution characteristics of mountainous runoff and its response to climate change in Xiying River Basin. Northwest Normal University. 2018, China.

18. ZHOU X.H. A comparative study of organic geochemical proxies in Holocene Aeolian and lacustrine sediments from the Shiyang River Basin. Lanzhou University. 2014, China.

19. ZHOU J.J., XUE D.X., LEI L., WANG L.Y., ZHONG G.S., LIU C.F., XIANG J., HUANG M.H., FENG W., LI Q.Q., ZHAO Y.R., ZHU G.F. Impacts of climate and land cover on soil organic carbon in the Eastern Qilian Mountains, China. Sustainability (Switzerland), 11, 5790, 2019.

20. ZHOU J.J., XIANG J., WANG L.Y., ZHONG G.S., ZHU G.F., WEI W., FENG W., HUANG M.H. Relationship between landscape pattern and hydrochemical characteristics of Binggou River Basin in eastern Qilian Mountains. Chinese Journal of Ecology, 38, 3779, 2019.

21. XU Z.F., LIU C.Q. Water geochemistry of the Xijiang basin rivers, South China: Chemical weathering and $\mathrm{CO}_{2}$ consumption. Applied Geochemistry, 25, 1603, 2010.

22. HUA K., XIAO J., LI S.J., LI Z. Analysis of hydrochemical characteristics and their controlling factors in the Fen River of China. Sustainable Cities and Society, 52, 101827, 2020.

23. World Health Organization. Guidelines for Drinking-water Quality $4^{\text {th }}$ Ed. 2011.

24. Ministry of Health. Standards for Drinking Water Quality. GB5749-2006.Ministry of Health of the People's Republic of China, Beijing.

25. WEN X.H., WU Y.Q., CHANG J., SU J.P., ZHANG Y.H., LIU F.M. Analysis on the Spatial Differentiation of Hydrochemical Characteristics in the Heihe River Watershed. ARID ZONE RESEARCH, 21, 1, 2014.

26. ZHOU J.X., DING Y.J., ZENG G.X., WU J.K., QIN J. Major ion chemistry of surface water in the upper reach of Shule River Basin and the possible controls. Environmental Science, 35, 3315, 2014.

XIAO J.Y., ZHAO P., LI W.H. Spatial characteristic and controlling factors of surface water hydrochemistry in the Tarim River Basin. Arid Land Geography, 39, 33, 2016.

27. HE J.Y., ZHANG D., ZHAO Z.Q. Spatial and temporal variations in hydrochemical composition of river water in Yellow River Basin, China. Chinese Journal of Ecology, 36, 1390, 2017.

28. ZHANG W.Y., MA L., ABUDUWAILI J, GE Y.X., ISSANOVA G., SAPAROV G. Hydrochemical characteristics and irrigation suitability of surface water in the Syr Darya River, Kazakhstan. Environmental Monitoring and Assessment, 191, 572, 2019.

29. LV J.M., AN Y.L., WU Q.X., LUO J., JIANG H. Hydrochemical characteristics and sources of Qingshuijiang River basin at wet season in Guizhou Province. Environmental Science, 36, 56, 2015.

30. MA J.Z., LI X.H., HUANG T.M., EDMUNDS W.M. Chemical Evolution and Recharge Characteristics of Water Resources in the Shiyang River Basin. Resources Science, 27, 117, 2005

31. XIANG J., ZHOU J.J., YANG J.C., HUANG M.H., FENG W., LI Q.Q., XUE D.X., ZHAO Y.R., ZHU G.F. Applying multivariate statistics for identification of groundwater chemistry and qualities in the Sugan Lake Basin, Northern Qinghai-Tibet Plateau, China. Journal of Mountain Science, 17, 448, 2020.

32. PAZAND K., KHOSRAVI D., GHADERI M.R., REZVANIANZADEH M.R. Identification of the hydrogeochemical processes and assessment of groundwater in a semi-arid region using major ion chemistry: A case study of Ardestan basin in Central Iran. Groundwater for Sustainable Development, 6, 245, 2018.

33. OU Y., WANG X.Y., GENG R.Z. The influences of different landscape characteristics on water quality in the upper watershed of Miyun Reservoir. Acta Scientiae Circumstantiae, 32, 1219, 2012

34. ZHANG X., LIU Y.Q., ZHOU L. Correlation analysis between landscape metrics and water quality under multiple scales. International Journal of Environmental Research and Public Health, 15, 1606, 2018. 
35. CAO C., ZHANG F., YALIKUN A., ZHU S.D., GUO M., TALIFUJIANG A., KUNG H. Relationship Between Landscape Pattern and Water Quality in the Ebinur Lake Region. Environmental Science, 39, 1568, 2018.
36. MA H.Y., ZHU G.F., ZHANG Y., PAN H.X., GUO H.W., JIA W.X., ZHOU J.J., YONG L.L., WAN Q.Z. The effects of runoff on Hydrochemistry in the Qilian Mountains: a case study of Xiying River Basin. Environmental Earth Sciences, 78, 1, 2019. 
